\title{
T NTERNATIONAL REACTIONS TO THE RUSSIAN SUPPRESSION OF THE POLISH INSURRECTION (NOVEMBER 1830)
}

\author{
Veniamin Ciobanu \\ “A. D. Xenopol" Institute of History \\ E-mail: veniamin@xenopol.iasi.astral.ro
}

\begin{abstract}
:
The outburst of the Polish insurrection and its evolution attracted the attention of the European Powers, due to the international political context in which it started, that of the liberal-bourgeois revolutions in France, Belgium, Germany, Italy, Spain, Portugal, and of the implications that were expected to occur due to power balance on the continent and in the Eastern Question. Russia's position in the political systems mentioned above depended on how the Polish Question would be solved. By subordinating all the Kingdom of Poland, whose political individuality, in the Russian political and institutional system, in which the decisions of the "Final Act" of the Peace Congress in Vienna (June 9th 1815) placed it, was about to be abolished by the Tsar, opened to the Russian Empire the path towards the consolidation of its positions in the Baltic region, strategically, political an economical, thus upsetting the other Powers in the European political system, on one hand. And secondly, because it would have relieved it of the necessity to divide its forces to oversee the evolution of the embarrassing Polish Question and would have been capable to focus its attention on a solution to the other problem, the Eastern one. This perspective was likely to happen, especially in the conditions of the peace Treaty that Russia had imposed to Turkey, at Adrianople, on September 14th 1829, which ensured the latter's "passivity" towards the Oriental policy of its victor.

These perspectives affected, in particular, Great Britain and France, the secular rivals of Russia in that area, so they tried, using only diplomatic means because of the very complicated international situation at the beginning of the fourth decade of the nineteenth century, to determine Russia to adopt a more conciliatory attitude towards the Polish insurgents.

The rivalries that aggravated the Franco-British relations, especially in Western Europe, prevented the two Powers to adopt a unitary position towards Russia, a fact that allowed the latter to dictate the law in the Kingdom of Poland.
\end{abstract}


A position, in some way singular, towards the Polish Question was adopted by another state, with direct interests in the Baltic sea area and with more specific ones in the Eastern Question. It is the United Kingdom of Sweden and Norway, created in the letter and the spirit of the Swedish-Norwegian Convention from Moss, on August 14th 1814.

Sweden's internal and external political circumstances in which, in 1810, the famous marshal of Napoleon I, Jean Baptiste Sebastien Bernadotte, prince of Pontecorvo, was proclaimed crown prince under the name Karl Johan, King Karl XIV Johan, from 1818, as the creation of the Swedish-Norwegian personal Union, determined the Swedish-Norwegian diplomacy favor the Russian interests in the Polish Question as well as in the Eastern Question. In the Polish Question, the one under our analysis, this was also because the insurrection of November 1830 started in the international conditions mentioned above and due to the fact that the liberal internal opposition to the conservative and absolutist monarchical policy of King Karl XIV Johan was becoming more active and could have constituted a reason for the Norwegians to evade the personal Union, which they did not favor and against which they fought, first through arms then by institutional means.

The forms in which Great Britain, France and Sweden took position in regard to the reprisal of the Polish insurrection of November 1830, very well documented by the diplomatic reports of the British diplomats in St. Petersburg and of the Swedish ones, accredited in Petersburg and in London, which we had the opportunity to consult in the funds of manuscripts of British Library, in London, and those of the National Archives of Sweden, in Stockholm, constitute, in our opinion, a contribution to the knowledge of the history of European diplomacy, on one hand, and to the research of the international relations in the first half of the nineteenth century, on another. This is the reason why we intend to approach them in this study.

All the documents selected from Sveriges Riksarkivet, in Stockholm and cited in these pages are included in the volume X, part I, of the Collection "Europe and the Porte", which is still in manuscript, for this reason we indicated the archive quotations.

\section{Rezumat:}

Declanşarea, la 29 noiembrie 1830, a insurecției poloneze şi evoluția acesteia au reținut atenția puterilor europene, mai mari sau mai mici, datorită atât imprejurărilor politice internaționale in care a debutat şi a evoluat, anume, revoluțiile burghezo-liberale din Franța, Belgia, Germania, Italia, Spania, Portugalia, cât şi implicațiilor pe care era de aşteptat să le antreneze, tocmai datorită acelor imprejurări, asupra raportului de forțe de pe Continent, cât şi a celui din problema orientală. Pentru că, de modalitatea în care avea să fie rezolvată problema poloneză depindea poziția pe care avea să o dobândească Rusia, în amintitele sisteme politice. În primul caz, deoarece, subordonând, în totalitate Regatul Poloniei, a cărui 
individualitate politică, în cadrul sistemului politic şi instituțional al Rusiei, în care îl plasase deciziile "Actului final" al Congresului de pace de la Viena, din 9 iunie 1815, urma să fie abolită de către țar, îi deschidea Imperiului Rus, pe de o parte, calea către consolidarea pozitiiilor sale în zona Mării Baltice, atât politico-strategice, cât şi economice, şi, pe cale de consecință, crearea oportunităților pentru a-şi exercita o influență supărătoare, pentru celelalte puteri europene, în sistemul politic european. Pe de alta, pentru că, nemaifiind obligată să-şi împartă forțele pentru a supraveghea evoluția atât de stânjenitoarei pentru ea, a problemei poloneze, putea să şi le concentreze pentru adjudecarea rezolvării celeilalte probleme, anume cea orientală, $\mathrm{cu}$ tot cortegiul de consecințe negative asupra sistemului politic european, pe de o parte, iar pe de alta, pentru interesele politice, strategice şi economice ale tuturor statelor europene care aveau câte ceva de apărat, unele mai mult, altele mai puțin, în zonele Mediteranei Orientale şi a celei a Mării Negre . Perspectivă ce părea a avea toate şansele de concretizare, mai ales in condițiile în care Tratatul de pace pe care îl dictase Turciei, la Adrianopol, la 14 septembrie 1829, î asigura "pasivitatea" acesteia față de politica orientală a învingătoarei sale. Deosebit de afectate de asemenea perspective s-au dovedit a fi fost, cum era şi firesc, Marea Britanie şi Franța, rivalele seculare ale Rusiei in acele zone, motiv pentru care au încercat, dar numai pe care diplomatică, din cauza foarte complicatei situații internaționale de la începutul celui de al patrulea deceniu al secolului al XIX-lea, să determine Rusia să adopte o poziție mult mai conciliantă faț̆ de insurgenții poloni. Rivalitătile care grevau şi raporturile franco-britanice, mai ales in Europa Apuseană, le-au impiedicat pe cele două puteri să adopte o poziție unitară față de Rusia, fapt ce i-a a permis acesteia să dicteze legea în Regatul Poloniei.

O poziție, oarecum singulară, faț̆ de problema poloneză a fost nevoit să adopte un alt stat, cu interese directe în zona Mării Baltice şi cu altele specifice în problema orientală. Este vorba de Regatul Unit al Suediei şi Norvegiei, creat în litera şi spiritul Convenției suedo-norvegiene, de la Moss, din 14 august 1814. Imprejurările politice, interne şi internaționale ale Suediei, în care a fost proclamat, în anul 1810, prinț moştenitor al tronului suedez, celebrul mareşal al Franței împăratului Napoleon I Bonaparte, Jean Baptiste Sebastien Bernadotte, prinț de Pontecorvo, sub numele de Karl Johan, devenit, din anul 1818, rege al Suediei, sub numele de Karl XIV Johan, ca şi crearea Uniunii personale suedo-norvegiene, îndeosebi, au determinat diplomația Suediei-Norvegiei să menajeze interesele Rusiei in problema poloneză, ca şi în cea orientală. În problema poloneză, in cazul de față, în cea concretă a insurecției din noiembrie 1830, şi pentru faptul că insurecția se declanşase în amintitele condiții internaționale, şi pe fondul activizării opoziției liberale interne față de politica conservatoare şi absolutist-monarhică a regelui Karl XIV Johan şi putea constitui un prilej binevenit pentru norvegieni de a se sustrage Uniunii personale cu Suedia, pe care nu o agreau şi impotriva căreia au luptat, mai întâi, prin forța armelor, apoi, pe cale instituțională. 
Formele în care s-au manifestat luările de poziție ale Marii Britanii, ale Franței şi ale Suediei, cele mai bine documentate de rapoartele diplomaților englezi, acreditaț la Petersburg şi a celolr suedezi, acreditați atât la Petersburg, cât şi la Londra, pe care am avut posibilitatea să le consultăm în fondurile de manuscrise de la British Library, din Londra, şi din cele ale Ahivelor Naționale ale Suediei, din Stockholm, față de reprimarea insurecției poloneze din noiembrie 1830, constituie, după părerea noastră, o contribuție la cunoaşterea istoriei diplomației europene, pe de o parte, iar pe de alta, la cercetarea istoriei relaților internaționale din prima jumătate a secolului al XIX-lea. Iată, aşadar, motivul pentru care ne-am propus să le abordăm in paginile acestui studiu.

Toate documentele selectate din Sveriges Riksarkivet, din Stockholm şi citate în cuprinsul acestor pagini, sunt incluse in vol. X, partea I, al Colecției "Europe and the Porte", aflat, $\hat{\imath} c \bar{a}, \hat{\imath} n$ manuscris; din acest motiv am indicat cotele din arhive.

Keywords: Poland, Russia, Great Britain, France, Sweden, insurrection

In the evening of November 29th 1830 , a small group of conspirators, under the leadership of Piotr Wysocki, attacked, by surprise, the residence from Belvedere, in Warsaw, of the Grand Duke Constantine, the brother of the Tsar Nicolas I and Supreme Commander of the Russian and Polish armies in the Kingdom of Poland, in order to capture him. The attempt failed because the Duke managed to take refuge in time. Unsuccessful was also the other part of the project that of taking the entire Polish army, quartered in Warsaw, out of the barracks. As a result, Piotr Wysocki, accompanied by a group of sub-officers, crossed the entire Warsaw, from South to North, in the Old city, where he managed, with the help of craftsmen and workers in the area, to capture the arsenal of the army. So, during the night and the next day, the population of Warsaw, which received arms, accompanied by several detachments of Polish soldiers who joined the conspirators, managed to capture the capital forcing the Russian army to withdraw from the city.

This is how the Polish insurrection started and become, in short time, an actual Polish-Russian war, carried out throughout Poland and Lithuania and lasted until October 21st 1831, when the last Polish military units surrendered to the Russian army at, la Zamość1. As a consequence, "The Kingdom of Poland was in the hands of Nicolas I, who started a ruthless campaign

\footnotetext{
1 Józef Andrzej Gierowski, Historia Polski 1764-1864, Warszawa 1985, Państwowe Wydawnictwo Naukowe, p. 181 and following. 90
} 
of reprisals. A brutal military occupation began that facilitated the liquidation of all the political features of Poland. The Polish state would maintain itself only by name" (s. n.) $)^{2}$.

The outburst, the evolution and then the repression of the Polish insurrection by Russia provoked a powerful emotion in Central and Western Europe. Along with the outburst of the revolutions in Europe, in 1830, the public opinion in these areas of Europe started to be concerned about the danger that Russia was posing to their security and liberty. The attitude the Tsar Nicolas I adopted towards those events created the conviction that Russia was on a diametrically opposed position to the principals of liberty, humanity and progress, promoted in the West of Europe. Thus "the Russian suppression of the Polish revolution, followed by the destruction of Polish independence, thereafter lifted Nicolas I to the apex of his infamy, as Western Europe saw it" (s. n) ${ }^{3}$. The liberal and democratic spirit in the Western Europe, expressed through genuine literature of several types, attributed to Poland the quality of being "the outpost of the West against the hostility of the Tsar toward revolutionary gains in Western Europe" (s. n)4. More than that even, it was considered that the outburst of the Polish insurrection "had diverted Russian forces from any possible crusade against liberalism in West during most of 1831" (s. n.) $)^{5}$. A free and powerful Poland also had the same meaning of "natural barrier against Tsarist pressure on Europe" in the opinion of some large, popular circles (s. n.) ${ }^{6}$. The speculations on this subject went so far that in the liberal circles of Europe it was considered that in order to be a strong barrier against the expansion of Russia, the territorial boundaries of Poland had to be wide enough for this mission. Besides the fact that it would have pushed Russia thousands of miles, removing it from Central Europe and reducing the number of populations under its domination, ", a Poland extending to the Black Sea would flank or bar Russian access to the Balkans, bringing relief to the decadent Turkish Empire and security in the Straits question" (s. n.) $)^{7}$. However, this role of Poland was seen as a result of a large Western coalition against Russia, liberal circles from some states attributing the role of leaders to France and

\footnotetext{
2 Ibidem, p. 193.

3 Oscar J. Hammen, Free Europe versus Russia, 1830-1854, in "American Slavic and East European Review, Vol. 11 (Feb.), 1952, p. 28.

4 Ibidem.

${ }^{5}$ Ibidem.

${ }^{6}$ Ibidem, p. 33.

${ }^{7}$ Ibidem, p. 34.
} 
Great Britain. However, the conflict of national interests between the European states was a serious impediment to the creation of a force capable to answer to this objective. This was the case of the two Great Powers, although the Belgian Question, triggered in 1830, contributed to an obvious closeness between them ${ }^{8}$. There were enough reasons to prevent them from collaborating in the stopping Russia's advance towards Central and Western Europe and this reality revealed itself when they approached the modalities of solving the Polish Question.

The outburst of a new revolution in Europe, that in Poland, held, as it was expected, the attention of the British diplomacy which tried to find out the causes and estimate its consequences on the European political system, in general, and for the British interest, in particular. It was expected that Russia would use this opportunity to annul the last concessions granted to the Poles by Alexander I and to consolidate its positions in the European political system. That is why the events in Poland were closely followed, even from their debut, by the Ambassador Extraordinary and Plenipotentiary of Great Britain to St. Petersburg, William A'Court, Baron Heytesbury9.

According to his opinion, expressed in a report addressed to Lord George Hamilton Gordon Aberdeen, the head of Foreign Office, on December 10 $10^{\text {th }} 1830$, with the outburst of the Polish insurrection, , another part of social edifice of Europe has begun to crumble" (s. n. $)^{10}$. A revolution which, "whatever be its ultimate result (and what that result will be, can scarcely be doubted, when we look at the Colossal Power to which the Poles are opposed) must inevitable render the unfortunate Country where it has exploded, a scene of present bloodshed, and devastation, which no success can compensate, the realisation (sic!) of no theories, repay" (s. n.) ${ }^{11}$. A prediction that was about to get real.

The British diplomat approached the issue of the Polish insurrection not from the point of view of its national objectives but from the perspective of Great Britain's interests, which, in the international circumstances from the beginning of the fourth decade of the nineteenth century, were aiming at keeping the continental peace. Thus, he considered that "under any other

\footnotetext{
8 Ibidem, p. 33.

${ }_{9}$ Veniamin Ciobanu, Debutul insurectiei poloneze din noiembrie 1830, în viziunea unui diplomat englez (in manuscript).

10 Ibidem.

11 Ibidem.

92
} 
circumstances - in any other times - it would be impossible not to wish well to the Poles, but our great object now is the Peace of Europe" (s. n.) ${ }^{12}$, which meant, no more, no less, that he thought that, in those tensed international circumstances with revolutions taking place in France and Belgium, the Polish insurrection was a serious threat to the continental peace, as long as it could constitute an opportunity for the Great European Powers to try to change the balance of power between them. That is why he thought that "we must not allow our feelings to get to the better of our reason" (s. n. $)^{13}$. This is why he had doubts in regard to the claims presented by the interim government of Poland to Nicolas I, as King of Poland, among which were the guarantee for the Constitution and the return to Poland of its former provinces, Volhynia and Lithuania, annexed by Russia. He considered that "that last of these demands is quite inadmissible" for Russia, and expressed his doubt that the Tsar would grant audience to the Polish delegation, which went to St. Petersburg to present these claims (s. n.) $)^{14}$. At most, as Karl (Carol) Vasilievici Nesselrode, Vice Chancellor and Foreign Minister of Russia, informed him, he would have received in audience the two members of the delegation not as official representatives but "as private Individuals” (s. n.) ${ }^{15}$.

According to the information sent by Magnus Fredrik Ferdinand Björnstierna, Minister of State and Foreign Affairs of Sweden, on December $14^{\text {th }} 1830$, the news about the Polish insurrection reached the capital of Great Britain two days earlier, on December $12^{\text {th }}$, and made already quite "une grande sensation" (s. n.) ${ }^{16}$. It was considered that this event, and not the revolution in Belgium, would configure the next war theater, as long as the Russian and Austrian armies will be sent against the Polish insurrection ${ }^{17}$. The Swedish diplomat made another interesting observation, he noted that "I'Angleterre entière sympathise avec les Polonais à l'exception de quelques "Ultra Toris » qui confondent la question avec celle du Jacobinisme" (s. n.) ${ }^{18}$.

As the news about the evolution of the events in the Kingdom of Poland were multiplying and diversifying, the sympathy of the English

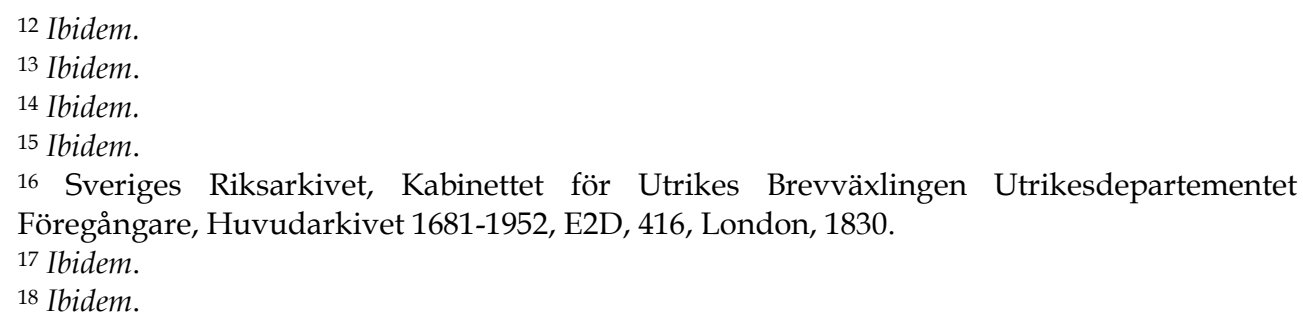


public opinion to the Poles grew and was expressed through press, regardless of its political or ideological orientation. Regarding the parameters in which the Polish insurrection was perceived by the British press, the Swedish diplomat stated that "on n'est point d'après elle une tendance révolutionnaire et Démocratique qui a crée ce mouvement", but "c'est celle du Patriotisme, c'est l'effet d'un peuple généreux, qui veut secouer le joug, que lui a imposé l'étranger par le partage le plus inique dont fait mention l'histoire, qui veut défendre une Constitution et des droits qu'on lui [été arraché?], presqu'aussitôt, qu'on les avait juré, et qui veut rétablir une Nationalité", que des siècles de gloire avait illustré" (s. n.) ${ }^{19}$. Making a parallel between the Belgian and the Polish Questions, the Swedish diplomat considered that a European war was more likely to start because of the latter. Regarding the position that Great Britain could have adopted, he thought that "ce ne sera, qu'à corps défendant, et à la dernière extrémité, qu'Elle prendra part à la conflagration générale" (s. n.) ${ }^{20}$. And as arguments to his point of view, he stated that, on one hand, Great Britain "a trop à faire dans son intérieur, pour s'occuper sérieusement des affaires de l'extérieure", and on another, that "son Commerce gagne trop par la Paix, pour être sacrifié aux chances de la guerre" (s. n.)21. The Ambassador of Great Britain to ST. Petersburg, William A'Court, Baron Heytesbury, also expressed his thought in this regard. Answering to the request of Karl (Carol) Vasilievici Nesselrode, Vice Chancellor and Foreign Minister of Russia, to transmit to his government Russia's desire that Britain should not intervene, in any way, in the Polish Question, the British diplomat assured him that "it was very unlikely $H$. M's Ministers would express any opinion tending to encourage resistance to the Emperor's authority" and that he was "quite certain not a syllable would be uttered in personal disparagement of one of H. M.'s oldest and most faithful Allies" (Russia - n. n.)22. Because, he claimed that, "the Emperor Nicolas's character was too well known, and too much respected in England, to admit of such a supposition"(s. n.) $)^{23}$.

\footnotetext{
19 Ibidem (his report from December 17th 1830).

20 Ibidem his report from January 7th 1831, in Sveriges Riksarkivet, Kabinettet för Utrikes Brevväxlingen Utrikesdepartementet Föregångare, Huvudarkivet 1681-1952, E2D, 417, London, 1831).

21 Ibidem.

22 His report from December 16 th 1830, addressed to the new head of the Foreign Office, Viscount Henry Temple Palmerston, in British Library, Department of the Western Manuscripts, Ms. Add. 41.560, f. 207-208v.

${ }^{23}$ Ibidem.

94
} 
Indeed, on December 31 st 1830, Henry Temple Palmerston exposed, in the Note addressed, at that time, to William A'Court, Baron Keytesbury, the point of view of the British Government, which the British diplomat had to present in St. Petersburg, regarding the way in which the Polish Question would be solved and the continental peace maintained. He was instructed to ensure the Russian government that "the first object of H. M.'s Gov being the maintenance of peace, they are convinced that nothing can tend more surely to the attainment of this object, than a good understanding between Russia and England, and as neither country has any selfish interests to pursue, the motives of their union cannot be misunderstood" (s. n.) ${ }^{24}$. For this purpose, the British government adopted the general principle "of non-interference in the Affairs of other countries, upon which it is their intention to act" (s. n.)25. Regarding the situation in the Kingdom of Poland, the Ambassador had to assure his Russian counterparts that "H. M.'s Govt have learnt with much concern the troubles which have broken out in Poland. Upon this delicate subject they cannot instinct you to make any communication to the Govt of H. I. M. But they cannot contemplate without shuddering the possible consequences of a war of extermination, to be waged between two nations, the one, goaded on by wounded pride and a devotion to their offended Sovereign, - the other excited by alleged grievances and ancient recollections, and desperate by the hopelessness of pardon. It is however much to be wished that during the interval that must claps before the season will admit of any considerable military operations, some arrangement may be effected between the Emperor and his Polish subjects, which may at once maintain the rights of the Sovereign, and remove any just cause of complaint from the Poles: and to such an arrangement, if an opportunity should be afforded in which you might offer your advice without offence to the Russian Govt, you will not fail to lend your best assistance" (s. n.) ${ }^{26}$.

This is how we can explain the fact that the Polish envoy, Marquis Wielopolski, sent to London to obtain the support of the British government, was not received by any British official until January 21 ${ }^{\text {st }} 1831$, as Magnus Fredrik Ferdinand Björnstierna found out ${ }^{27}$.

\footnotetext{
24 British Library, Department of the Western Manuscripts, Ms. Add. 41.560, f. 235-238.

25 Ibidem.

26 Ibidem.

27 His report from January 21st 1831 , in Sveriges Riksarkivet, Kabinettet för Utrikes Brevväxlingen Utrikesdepartementet Föregångare, Huvudarkivet 1681-1952, E2D, 417, London, 1831; instead he thought that "il trouvera une grande sympathie pour Sa cause dans ce
} 
The general enthusiasm provoked in Great Britain by the victories of the insurgents over the Russian armies sent against them in the spring of 1831 had no consequences and did not help the Polish cause in any way. However, as Björnstierna estimate, this state of spirit "ne peut manquer d'influer favorablement sur elle, quand le temps sera venue, de régler cette question sous ses rapports de Politique Européenne" (s. n.) ${ }^{28}$. Because, he explained, "l'opinion dans un Etat Constitutionnel, tel que l'Angleterre est tout. Elle est plus que la Reine, elle est le Roi du Pays, et garde à celui qui oserait la braver" (s. n.) ${ }^{29}$.

The victory of the revolution in France, in July 1830, provoked a serious tension in the international relations. The most affected by the overthrow of the last representative of the Bourbon dynasty from the throne of France, King Charles X, and the election of Louis Philippe as King, proved to be the Tsar Nicolas I. This was because these events violated the principle of the monarchic legitimacy, whose "champion" he was. Instead, as was asserted in the historiography of the problem, Nicolas I, considered this a good opportunity to became "le héros d'une seconde restauration française; son imagination fut surtout sensible à l'éclat dont sa couronne serait environnée s'il s'emparait aux yeux de l'Europe entière du rôle de patron de la légitimité, d'adversaire résolu des idée libérales, et de redresser des torts des peuples" (s. n.) ${ }^{30}$. Thus, he categorically refused to recognize the new authorities in Paris ${ }^{31}$,

Pays-ci, où tous les partis (Tories, Whigs et Radicaux) font des voux sincères pour la Pologne", but which, "cependant finiront, je pense, à n'être que des vœux" (s. n.) (ibidem); on March $24^{\text {th }} 1831$, he transmited to Stockholm the information according to which "j'ai lieu de croire, que le Gouvernement Anglais evera un Consul Général en Pologne dont l'indépendance se trouve garantie par la signature du Traité de Vienne" (s. n.) (ibidem).

${ }^{28}$ His report from April 12 th 1831 , in ibidem.

${ }^{29}$ Ibidem; connoisseur of the state of spirit in the British society, he wanted to take precaution measures regarding his commentaries on the Polish Question, stating that "je supprime ici autant que possible, mes opinions, car là où les passions son en jeu, l'impartialité a le malheur de déplaire des deux côtés. Il vaut donc mieux me taire, au risque de passer pour un inepte" (s. n.) (ibidem). 30 Histoire de la politique extérieure du Gouvernement Français 1830-1848. Avec notes, pieces justificative et documents diplomatiques entièrement inédits. Par M. O. D'Haussonville, Ancien député I, Nouvelle edition, Paris Michel Lévy, Libraires-Éditeurs, 1850, p. 98-99 (following, M.O. D’Haussonville, op. cit.)

31 With the occasion of an audience, which he granted to Paul de Bourgoing, the French Chargé d'Afaires, Nicolas I addressed him with an irritated tone: „avez vous reçu des nouvelles de votre gouvernement, c'est-à-dire de M. le lieutenant général ? (King Louis Philippe - n. n.) car vous savez que je ne reconnais aucun ordre de choses que celui-là, et que je le considère comme seul légal, parce que seul il découle de l'autorité royale légitime...Oui, répétait-il à M. de Bourgoing...oui, tel est ma façon de penser: le principe de la légitimité, voilà ce qui me guidera en toute circonstance; je ne m'en départirai jamais...jamais je ne pourrai approuver ce qui vient de se passer en France" (s. n.) (ibidem, p. 100-101). 
because he was convinced that no other European Power will. His assumption proved, in short time, to be wrong, as the European Powers, including Prussia and Austria, his allies, on whose collaboration the Tsar counted, hastened to regulate their relations with France. So that he had to recognize, officially, the new King, Louis Philippe, and his government, thus Victor Emanuel de Mortemart came back to his post, as Ambassador of France at St. Petersburg, reestablishing France's diplomatic relations with Russia $^{32}$.

The official normalization of the Russo-French relations have relieved the crisis in the international relations, provoked by the events of July 1830, the only issue remaining, in the opinion of Magnus Fredrik Ferdinand Björnstierna, was the Polish Question "qui puisse encore mettre des obstacles au parfait retablissement de la tranquillité" in Europe (s. n.) ${ }^{33}$. Russia refused the offers of British and French mediation in its relation with the Polish insurgents and the Tsar only promised a general pardon, but only "quand une fois la Pologne se sera de nouveau soumise" (s. n.) ${ }^{34}$. However, the Swedish diplomat presumed that, because of "les vîs pacifiques" of the French government, led by Casimir Pierre Perier, as of the similar ones of the British government, chaired by Charles Grey, "après avoir fait ce qu'exigent l'Humanité et la générosité des au-delà, mais reposant sur la majorité de leurs Parlemens respectifs, que régit l'influence de l'opinion, il serrait possible, que cellesci les entraine à des mesures, que je considère contraires à leurs désires" (s. n.) ${ }^{35}$. An attitude that was more desirable as the rumor that a British fleet under the command of Admiral Codington, an "Ultra-libéral dans ses principes”, was about to sail to the Baltic sea, was spreading (s. n.) ${ }^{36}$. Still, the Swedish diplomat had to admit the fact that "rien ne rendrait le Ministère plus populaire qu'une intervention armée en faveur de la Pologne, depuis que celle de la diplomatie a manqué", if "il n'y a qu'une voix la dessus dans toute l'Europe" (s. n) ${ }^{37}$.

\footnotetext{
32 Ibidem, p. 103 and following; „le czar - nota M. O. D'Haussonville - comprit cette nécessité; ce qui lui fut impossible, ce fut de l'accepter de bon grâce. Il lui en coûtait trop d'avoir à revenir complètement sur les maximes qu'il avait, dans le premier moment, professées avec plus d'impétuosité que de réflexion" (s. n.) (ibidem, p. 104).

${ }^{33}$ His report from May 20th 1831 , in Sveriges Riksarkivet, Kabinettet för Utrikes Brevväxlingen Utrikesdepartementet Föregångare, Huvudarkivet 1681-1952, E2D, 417, London, 1831.

34 Ibidem.

35 His report from May 20 th 1831 , in ibidem.

${ }^{36}$ His report from May 31 st 1831, in ibidem.

37 Ibidem; Björnstjerna based his judgments on the fact that "l'Angleterre est sur les meilleurs terms avec la France. Je crois cet accord généralement populaire en Angleterre, et l'être en France aussi
} 
Nevertheless, there was not any reason to believe that a new international crisis would outburst, determined by the Polish Question, opinion shared also by the Ambassador of Russia to London, Khristofor Andreevici Liven, who did not exclude the possibility of such crisis if England would have intervened in the Polish Question ${ }^{38}$.

The events that took place in Western Europe in the second part of 1831 and in the beginning of the following year, determined an obvious tension in the relations between France and Britain. The French expedition in Portugal, the occupation, by the French troupes of Anvers, the military intervention in the Northern Italy, supporting the revolution started there against the Austrian authority and, especially, the way in which the French occupied Ancône, a city on the territory of the Papal States ${ }^{39}$, provoked not only the irritation of the Holy Chair ${ }^{40}$, but also that of the British government, "malgré la bonne intelligence, qui règne dans ce moment entre les deux Gouvernements, et leur sujets respectifs". These French expeditions in Italy were perceived "avec beaucoup de jalousie et de méfiance” in Great Britain (s. n. $)^{41}$. The most accentuated indisposition was provoked by the expedition in

dans les classes moyennant élevées de la Société. Ces différents faits contribueront à faire juger à Votre Excellence de la crise qui peut avoir lieu. Je suis cependant fort loin encore d'affirmer qu'elle doit avoir lieu" (s. n.) (ibidem).

38 On July 22nd 1831, Magnus Frederik Ferdinand Björnstierna informed Count Gustaf Wetterstedt about the fact that "le Prince de Lieven m'a dit avant hier, qu'il n'avait encore êu aucune communication, qui puisse donner lieu à croire que la Grand Bretagne voulût intervenir dans les affaires de la Pologne, que cela pouvait bien arriver d'un jour à l'autre, mais que jusqu'ici, rien ne c'était fait dans ce sens" (s. n.) (ibidem); referring to the news regarding the possibility of British fleet heading to the Baltic sea, Björnstierna, in an annex to a report from July $29^{\text {th }} 1831$, hastened to reassure the Swedish ruling circles, concerned by the possibility that Great Britain would have followed some objectives which could have affected the security of Sweden, stating, in an annex to a report from July $29^{\text {th }} 1831$, that "la parfaite indifférence avec laquelle le Prince de Lieven a pris cet armement dans ses relations avec le Gouvernement Anglais, quoique, comme moi, il n'a pas manqué d'y fixer l'attention de Sa Cour, me sert de guide, d'autant plus que cet armement pouvait être hostile à la Russie, mais ne pouvait jamais être à la Suède" (s. n.) (ibidem).

39 Occupation carried out at night „et sans avis préalable avec toutes les apparences d'une attaque de vive force" (s. n) (M.O. D'Haussonville, op. cit., p. 38; for other details concerning the events mentioned, see ibidem, p. 20 and following; p. 32 and following).

40 Ibidem, p. 38.

41 The report of A. W. Råland, Chargé d'Affaires ad interim of Sweden to London, to Count Gustaf Wetterstedt, on March 9th 1832, in Sveriges Riksarkivet, Kabinettet för Utrikes Brevväxlingen Utrikesdepartementet Föregångare, Huvudarkivet 1681-1952, E2D, 418, London, 1832; the irritation of the British ruling circles was so accentuated that not even the explanations of the French Prime Minister, Casimir Pierre Perier, could not calm the spirits, the problem being a subject of debate in the House of Lords (his report from March 16 ${ }^{\text {th }} 1832$, in ibidem).

98 
Portugal, which the leading circles in Britain considered to be a threat to the commercial interests of Great Britain, because Portugal was an important market for the British industrial products and had strategic importance because it was a "bridgehead" in the Iberian Peninsula. The consequences of that rivalry were felt in Franco-British collaboration in the Polish Question, and France was suspected that it tried to strengthen its position in Europe, a fact considered more dangerous for the British interests than the "solving" of the Polish Question by Russia alone, "une Puissance aussi éloignée” from Western Europe(s. n. $)^{42}$.

However, the British government could not ignore the attachment of the public opinion to the Polish cause. That is why, we believe, that in order to offer it some satisfaction, it tried to determine, using diplomacy, the Tsar to adopt a more conciliatory attitude towards the Polish insurgents, after the conclusion of the military operations against the insurrection, in October 1831.

The issue on the agenda was the intention of the Tsar to impose to the Kingdom of Poland a "constitution" which was considered to be inappropriate to the rights of the Poles. That is why, on November 23rd 1831, Henry John Temple, Viscount Palmerston, Secretary of Foreign Office, mandated the Ambassador of Great Britain to St. Petersburg, William A'Court, Baron Heytesbury, to inform the Tsar on the British point of view regarding a solution for the Polish Question.

Thus, starting from the fact that "the War (against the Polish insurrection - n. n.) being now over, and the authority of the Emperor (Nicolas I - n. n.) as King (of Poland - n. n.) being completely re-established in Poland", the British government considered that "the time is come when His Majesty (King of Great Britain, William IV) feels himself justified, both by his friendship for the Emperor of Russia and by duty resulting from the obligations which he had contracted under the treaty of Vienna ${ }^{43}$, in addressing to His Imperial Majesty, in

42 The report of Magnus Fredrik Ferdinand Björnstierna, from August $26^{\text {th }} 1831$, in ibidem).
43 He was referring to the Peace Treaty of Vienna, concluded on June 9th 1815 ; according to
Art. I of the "Final Act”, "The Duchy of Warsaw, with the exception of the provinces and districts
which are otherwise disposed of by the following Articles is united to the Russian Empire. Il shell be
irrevocably attached to it by its Constitution, and be possessed by His Majesty, the Emperor of all
Russias, his heirs and successors in perpetuity. His Imperial, Majesty reserves to himself to give to this
State, enjoying a distinct administration, the interior improvement which we shall judge proper. He
shall assume with his other titles hat of Czar, King of Poland, agreeable to the form established for the
titles attached to His other possessions" (s. n.) (The Map of Europe by Treaty showing the various
Political land Territorial Changes which have taken place since the general peace of 1814. With 
the most amicable tone, and with the deference which is due to his rights as an independent Sovereign, some observations as to the best mode of re-settling the Kingdom of Poland under the dominion of the Emperor, on principles accordant with those on which its Union with the Imperial Crown of Russia was originally formed, and in such a manner as may be most conducive to its good government and

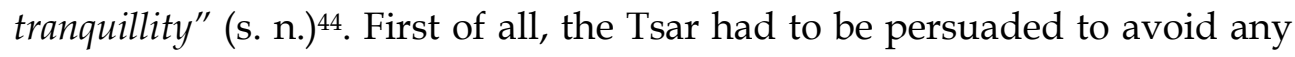
kind of collective reprisals against the insurgents, the British government recommending him to grant "a full and complete Amnesty, from which those persons only should excepted who have been guilty of the crime of assassination"; in such cases, only with the condition that the punishment should be applied "by the ordinary course of justice" (s. n.) ${ }^{45}$. And to convince him about the necessity of such an attitude, his attention was drawn towards a certain reality, honorable for the Poles, which he had to take into account. Namely that "the Poles have displayed, during the late war (between them and Russia n. n.), qualities both of intellect and courage, which prove them capable of being either useful or dangerous subjects, according to the manner in which they may be governed" (s. n) ${ }^{46}$. Therefore, the Tsar's intention to repeal the Constitution granted to the Kingdom of Poland through the "Final Act" of the Peace Treaty from Vienna, meant, in the opinion of the British government, "to reduce that Kingdom, though still nominally possessing a separate existence, to the state and condition of a province, deprived of all rights, and excluded from all the advantages which had been secures to it" (s. n.) ${ }^{47}$. Therefore, the fact that the Poles rebelled and even voted for the removal of the Tsar from Poland's throne, violating, themselves, the letter and the spirit of their Constitution, granted by the Congress of Vienna ${ }^{48}$, could not absolve the Tsar, after his authority was restored in Poland "from his obligation to adhere to that Constitution" (s. n.) ${ }^{49}$. Because, in the opinion of the British government,

\footnotetext{
Numerous Maps and Notes, Vol II, by Edward Herstelet C. B., London 1875, p. 208 and following. (Following, Map of Europe, Vol II).

44 Ibidem, p. 875.

${ }^{45}$ Ibidem, p. 876.

46 Ibidem, p. 877.

47 Ibidem.

48 In compliance with the decisions of the Seim, from January 25th 1831 (Józef Andrzej Gierowski, Historia Polski 1764-1864, Warszawa, 1985, Państwowe Wydawnictwo Naukowe, p. 184.

${ }^{49}$ Map of Europe, Vol. II, p. 879.

100
} 
"wrongs committed by one side are not to be punished by the commission of wrongs on the other" (s. n.) $)^{50}$.

Russia's answer to Great Britain's protest was sent through its Ambassador in London, Khristofor Andreevici Liven. The terms of the Dispatch, dated December $22^{\text {nd }} 1831 /$ January $3^{\text {rd }} 1832$ and signed by the Vice Chancellor Karl (Carol) Robert Vasilievici Nesselrode, left room for no interpretation. First of all, it stated that the Tsar did not commit and did not intend to commit, regarding the manner of approach of the Polish insurrection, no infringement to the Peace Treaty of Vienna. However, he considered this question to be an exclusive internal problem of Russia. That is why, "he is thoroughly determined to admit no Foreign Intervention in questions which concern him exclusively" (s. n.) ${ }^{51}$. Because, in a more close examination of the stipulations regarding Poland, inserted in the "Final Act" of the Vienna Peace treaty, from June $9^{\text {th }} 1815$, the following conclusion would have been reached, "with no other view than to express that the Union of the Kingdom to Russia must be the fundamental principle and the condition of its new existence" (s. n. $)^{52}$. Because the Constitution that Tsar Alexander I granted to the Kingdom of Poland "was not a necessary consequence of the Treaty of Vienna, but a spontaneous act of his sovereign power" (s. n) ${ }^{53}$. The natural conclusion, in the acception of the Russian diplomacy was that ,if the Constitution of Poland had been given in conformity with the Treaty of Vienna, The Contracting Powers would have had the right to take cognizance of it, and to examine whether it answered to the engagements entered into by Russia" (s. n.)54. Or, "none of them claimed this right, nor could they legally do so" (s. n.) 55 . On the contrary, all of them recognized, by ignoring this subject, that "in granting this Constitution to the new subjects the Emperor had followed the dictates of his free will" (s. n.) ${ }^{56}$. These arguments and many others invoked by Vice Chancellor Nesselrode, in the Dispatch, among them the one according to which the Poles themselves annulled the Kingdom's Constitution by their rebellion and the proclamation of the removal of Tsar Nicolas I from Poland's throne ${ }^{57}$, had to

\footnotetext{
50 Ibidem; for the entire document, see ibidem, p. 875 and following.

${ }^{51}$ Ibidem, p. 886.

52 Ibidem.

53 Ibidem.

54 Ibidem.

55 Ibidem.

56 Ibidem.

57 Ibidem.
} 
lead the British government to the conclusion that, as long as the Tsar was making efforts to restore the "moral peace" in Poland and to gradually achieve a "sincere reconciliation" between Poles and Russian, the two "nations" united under the same scepter, any encouragement to those who opposed their legitimate government would have had disastrous consequences. Especially, the Tsar was expecting the British government, in the name of the friendship between the two governments, to favor him and to restrain itself from any intervention in Russia's relations with the Polish Kingdom $^{58}$.

Nicolas I was convinced that maintaining the autonomy of the Kingdom of Poland "would have served only for the outburst of other revolutions" 59. A reason for which he "considered the Constitution as being not mandatory and, in 1832, he issued the so-called Organic Statute, which severely limitated the individuality of the Kingdom, making the first step towards its integration in the Empire" 60.

In order to justify its necessity, in the text of the Statute, dated February $28^{\text {th }} 1832$, there were accused those Poles who, being enemies of the "order" and "legitimate power" of Russia and "dreaming of separation of the two countries subject to our sceptre (Kingdom of Poland and Russia - n. n.), they have abused the benefits of the regeneration of their country, and have used as a means to overthrow his work the privileges and constitutions which they possessed exclusively from his sovereign will" (s. n.) ${ }^{61}$. The consequence was the civil war that brought the country into ruins, a situation rectified by the restoration of peace and the return of the Kingdom under the power of the Tsar, who was

\footnotetext{
58 Ibidem, p. 889-890; for the entire document, see ibidem, p. 885 and following.

59 Józef Andrzej Gierowski, op. cit., p. 218.

60 Ibidem; "the coronation (of the Tsar as King of Poland, at Warsaw - n. n.), the Seim, and the Polish army were abolished. The entire legislative power belonged to the monarch. The State Council and a reduced Administrative were kept for the moment but they depended, in a greater extent, on the Governor. It was decided to keep the Polish language as official language, and the civil and criminal Polish legislation finally granted - but only on paper - civil liberties. In reality, due to the martial status of the Kingdom, the most important decisions were taken by the Governor, a man who conquered back Warsaw (from the Polish insurgents - n. n.), [Ivan] Paskievici-Erevanski, and by the military commanders. Besides, the State Council was formed, mostly, of members recruited from Russia. The Organic Statute was never applied; in exchange, the process of assimilation of the rapports that existed in the Kingdom by the ones in Russia, started" (s. n.) (ibidem, op. cit., p. 218); for the text of the Organic Statute, see Konstytucje Polskie 1791-1821. Wydał Marceli Handelsman. Wydanie trzecie poprawione, Nakładem S.K.I. AKC, Polska Składnia Pomocy Szkolnych, Warszawa, 1922, p. 100 and following.

${ }^{61}$ Map of Europe, Vol. II, p. 891.

102
} 
determined to avoid the outburst of such "tragedies" in the future. At the same time, he expressed his wish "that our subjects of the Kingdom of Poland should enjoy all the advantages necessary to their wellbeing and the prosperity of their country; that the respect for persons and property, liberty of Commerce, and municipal franchise, should be maintained; that they should have a distinct Administration, in conformity with their wants, in such manner as that the Kingdom of Poland may never cease to form an integral part of our Empire, and that they may in future make with the Russians but one nation, one people of brothers" (s. n. $)^{62}$.

However, the promulgation of Statute displeased the British government, which maintained the position according to which the Polish insurrection did not gave to the Tsar the right to annul the Constitution which was granted to the Kingdom by Alexander I and was guaranteed by the "Final Act” of the Congress of Vienna, especially because Britain was among the Powers which signed it.

In consequence, at the end of June 1832, it decided to send Lord Durham to St. Petersburg, with the mission, as A. M. Röland thought, "d'obtenir du Gouvernement Impérial quelques concessions en faveur de la Pologne" (s. n. $)^{63}$.

The instruction given to Lord Durham, signed by Henry John Palmerston, on July $8^{\text {th }} 1832$, underlined the desire of British government to avoid any military conflict with Russia over the Polish Question. His mission would have been successful only if the four Great Powers, meaning Great Britain, France, Austria and Prussia, would have acted in the same manner. The reality was completely different, Austria and Prussia were supported Russia's point of view regarding the interpretation of the stipulations referring to Poland in the "Final Act" of the Peace Treaty of Vienna. The only Powers which "stood their ground" were Britain and France, but they could succeed only by arms, a possibility that was out of the question. This is why Lord Durham had to approach the problem with "delicacy" and "precaution"64. However, the emissary had to persuade his counterparts to understand the fact that the British government did not approve to the

\footnotetext{
62 Ibidem, p. 892.

${ }^{63}$ His report from June 29th 1832 , in Sveriges Riksarkivet, Kabinettet för Utrikes Brevväxlingen Utrikesdepartementet Föregångare, Huvudarkivet 1681-1952, E2D, 418, London, 1832; according to his information, the Polish Question was the subject of fierce debate in the House of Commons, in the evening of June $28^{\text {th }} 1832$ (ibidem).

${ }^{64}$ Map of Europe, Vol. II, p. 900-901.
} 
modification of the Polish Constitution and to other measures undertaken already or pending. Among those, "the abolition of the Polish Colors; the introduction of the Russian Language into public acts; the removal to Russia of the National Library, and public collections containing bequests made by individuals upon specific condition that they never should be taken out of the Kingdom of Poland; the suppression of Schools and other establishments for public instruction; the removal of a great number of Children to Russia on the pretence of educating them at the public expense; the transportation of whole families to the interior of Russia; the extent and severity of the military Conscription; the large introduction of Russians into the public employments in Poland; the interference with the national Church" - all being symptoms "of a deliberate intention to obliterate the political nationality of Poland, and gradually convert it into a Russia province" (s. n.) ${ }^{65}$. Lord Durham was instructed to verify if all these abuses were true, and if they were he had to use this opportunity to urge the Russian government, but "with the earnestness, and the same time with the freedom of a sincere friend, to adopt a milder and juster system", highlighting the fact that the British government justified its right to intervene through the stipulations of the Treaty of Vienna (s. n. ${ }^{66}$. In the end of these instructions, he was warned to always have in mind Great Britain's interest "to cultivate and increase, if possible, the friendly relations now so happily subsisting between this country and Russia", at the same time, having to assure Tsar Nicolas I "of sincere and cordial friendship which His Majesty entertains for His Imperial Majesty, and of declaring His Majesty's desire to maintain, and, if possible, to draw closer the bond of alliance which connect two Powers whose union must have so salutary an effect in preserving the Peace of the World" (s. n) ${ }^{67}$.

An intervention undertaken under such auspices was bound from the start to fail. The signs were obvious, even from the moment it was designed. Thus, on the occasion of the negotiations that the Russian Ambassador to London, Khristofor Andreevici Liven, held with Charles Grey, head of the British government, the fact that Lord Durham's mission

\footnotetext{
65 Ibidem, p. 901-902; in connection with this last intention of Russia, it was stated that this kind of project was unachievable because it was impossible "to change 4,000,000 of Poles so entirely as to impart to them the character of Russians in an attempt for the success of which it would be difficult to assign a limit, either of time or perseverance"; on the contrary, such an attempt "would lead to a severe and continual exertion of arbitrary power, which would create a strong and general feeling against Russia, and must be regarded as a decided violation of the engagements contracted by Russia at Vienna in 1815" (s. n. ) (ibidem, p. 902).

66 Ibidem.

67 Ibidem.
}

104 
would not have the results expected was obvious. Because, the Russian diplomat "s'est prononcé, dit-on, de la manière la plus distincte en exprimant ses craintes de l'accueil peu satisfaisant auquel pourrait s'exposer un négociateur chargé d'une pareille mission, et sa conviction de la ferme résolution de l'Empereur (Nicolas I - n. n.) de ne changer en rien la ligne qu'il s'est tracé à l'égard des affaires de la Pologne" (s. n.) ${ }^{68}$. Then, as A. W. Röland, Sweden's Chargé d'Affaires ad interim to London, thought, even if Great Britain would have justified its right to intervene in the Polish Question, invoking it quality as guarantor of the Polish Constitution, stipulated in the "Final Act” of the Congress of Vienna, his demarches were late. It would have been successful if it had been undertaken several months before, more precisely at the end of the insurrection, "cause primitive des mesures de rigueurs, dont croit devoir se plaindre maintenant sur la cessation desquelles il est dit que Lord Durham est chargé d'insister de la manière la plus prononcée" (s. n.) ${ }^{69}$. And, indeed, Lord Durham completed his mission, assuring Vice Chancellor Karl (Carol) Robert Vasilievici Nesselrode "que c'était là une discussion terminée des le mois de Février entre le Comte (Nesselrode - n. n.) et lord Heytesbury (s. n.) $)^{70}$. Thus, he was complying to one of the indication inserted in his instructions, according to which he had to refer, during the negotiations, "to the representations already made upon this subject by Her Majesty's Ambassador at the Court of St. Petersburg (William A'Court, Baron Heytesbury - n. n.), but you will not press this matter in such a manner as, without producing any benefit to Poland, would incur the hazard of increasing the difficulties already existing on the various subjects to which your attention has been called in this dispatch" (s. n.) ${ }^{71}$.

68 The dispatch of A. W. Röland, from July $3^{\text {rd }}$ 1832, in Sveriges Riksarkivet, Kabinettet för Utrikes Brevväxlingen Utrikesdepartementet Föregångare, Huvudarkivet 1681-1952, E2D, 418, London, 1832.

${ }^{69} \mathrm{Ibidem}$; the Swedish diplomat also suggested that there was another cause which could have determined the failure of Lord Durham's mission: "le caractère hautain et peu pliant du négociateur, joint à ses principes trop connus d'un libéralisme presque outré, semble aussi être d'un fâcheux augure pour la réussite de sa mission"; plus, "quoique homme de talent, on craint que Lord Durham ne possède point les qualité nécessaires pour entamer avec quelque succès un négociation d'une nature aussi délicate" (s. n.) (ibidem).

70 The report of Nils Gustaf Pelmtierna, to the Chancellor of the Swedish Royal Court, David Schulzenheim, from August 18 ${ }^{\text {th }} / 6^{\text {th }} 1832$, in Sveriges Riksarkivet, Kabinettet för Utrikes Brevväxlingen Utrikesdepartementet Föregångare, Huvudarkivet 1681-1952, E2D, 703, Petersburg, 1832, jan.-16/10.

71 Map of Europe, Vol. II, p. 901; referring to these instructions, Nils Fredrik Palmstierna, Sweden's Chargé d'Affaires to St. Petersburg, noted, in the report addressed to Count Gustaf Wetterstedt, his Foreign Minister, that "les dernières instructions de l'Ambassadeur Anglais relativement aux affaires de la Pologne, n'impliquent point l'adhésion de son Gouvernement aux vues 
The revolutionary origins and the circumstances of the establishment of the July monarchy in France provoked a great anxiety in Europe ${ }^{72}$. However, some European states rapidly recognized the political regime created by the revolution of July. First of those states was Great Britain, with the condition that France respects the existing international treaties and to try not to provoke new turmoil in Europe ${ }^{73}$. Austria and Prussia followed, and eventually Russia, which „annonçaient, en termes tout aussi formels, leur résolution de maintenir le statu quo territorial de l'Europe, tel qu'il avait été réglé par le congrès de Vienne, et de ne souffrir aucune tentative de propagande révolutionnaire" (s. n.) $)^{74}$.

Confronted with such serious difficulties, the new French government did not hesitate to adopt one of those principles "qui décident de

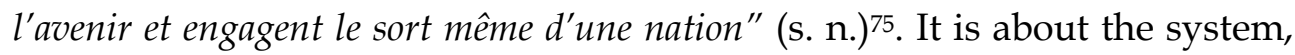
later called "de non intervention"(s. n.), stated by the Foreign Minister, Louis, Conte Molé, which, in those circumstances, corresponded in the highest grade to the needs of France but which provoked a strong irritation to Austria , Prussia and Russia. Because, the new principle of the French foreign policy not only it did not guaranteed, in those European circumstances, their interests, on the contrary, "il devait finir par tourner contre elles" (s. n.) ${ }^{76}$.

que la Russie avait annoncées, concernant l'organisation de ce pays. Il parait néanmoins qu'on ne proteste qu'à peu près pour la forme, sans amertume, et probablement pas avec l'intention d'insister" (s. n.) (Sveriges Riksarkivet, Kabinettet för Utrikes Brevväxlingen Utrikesdepartementet Föregångare, Huvudarkivet 1681-1952, E2D, 703, Petersburg, 1832, jan.-16/10).

72 „Les événemens de Paris - noted Magnus Fredrik Ferdinand Björnstierna in his report to Count Gustaf Wettterstedt, on December $24^{\text {th }} 1830$ - me confirm dans l'opinion, que le régim de Napoleon est le seul adaptable au Caractère Francais, qui ne connaitra la liberté sans tomber dans la licence"; however, he accepted the fact that ",bien d'autre Peuples sont dans le même cas"; still, he noticed that, "il y a cependant d'honorables exceptions, et l'on ne peut nier que l'Angleterre n'en fasse une" (s. n.) (Sveriges Riksarkivet, Kabinettet för Utrikes Brevväxlingen Utrikesdepartementet Föregångare, Huvudarkivet 1681-1952, E2D, 416, London, 1830).

73 M. O. D'Haussonville, op. cit., p. 16.

74 Ibidem, p. 17.

75 Ibidem.

76 Ibidem, p. 17-18; Prince Klemens Wenzel Nepomuk Lothar von Metternich Winneberg zu Beilstein, Foreign Minister of Austria, proved to be the most convinced of this danger; according to the information sent to Paris, in September 1830, by the French Chargé d'Affaires to Vienna, he strongly protested "contre la prétention étrange du gouvernement francais d'introduire, pour sa convenance, un nouveau droit des gens don ton n'avait jusque-là jamais entendu parler, et qui été purement et simplement le renversement de toutes les règles qui avaient jusqu'alors présidé à la politique des états européens" (s. n.) (ibidem, p. 10-11).

106 
This principle proved to be quite efficient in solving the Belgian Question but, in the same time harmful, when applied to the Polish Question. The idea of a military intervention in favor of the Polish insurgents being out of the question, due of the principle mentioned above ${ }^{77}$, the new French government started a sustained diplomatic campaign, in order to obtain the collaboration of the European Powers directly interested in this question. The demarches undertook in Vienna by the French cabinet, "pour s'assurer le concours moral de l'Autriche dans un but de paix et d'humanité" (s. $\mathrm{n}$. ${ }^{78}$, were undermined by Austria's interests in the Polish Question, on one hand, and by "la crainte de blesser les susceptibilités de l'empereur de Russie”, on another (s. n.) $)^{79}$. Thus, the efforts of the French government "pour entrener le cabinet de Vienne à une intervention pacifique, soit pendant la lutte, afin d'arrêter l'effusion du sang, soit plus tard, quand vint l'issu fatale, afin de prévenir l'atteinte dont les traités étaient menacés (the Treaties from Vienna, in 1815 - n. n.), ne furent malheureusement accueillis que par des réponses évasives, ou stériles protestations" (s. n.) ${ }^{80}$. The same fate was shared by the attempts to determine Prussia to, at least, restrain from giving Russia any direct support in the suppression of the Polish insurrection ${ }^{81}$.

77 Although Magnus Fredrik Ferdinand Björnstiera, in a report sent to Count Gustaf Wetterstedt, on December $21^{\text {st }} 1830$, expressed his conviction „ que la France étendra Son bouclier protecteur sur l'indépendance de la Pologne et ne permettra point à l'Autriche ni à la Prusse d'intervenir dans la question Russo-Polonaise sans être attaquées dans les Provinceda du Rhin ou dans celles de l'Italie qui sont prètes l'une et l'autre à se soulever à la voix de la France. Que la Pologne se défende jusqu'à l'ouverture de la Navigation et Elle est sauvée" (he was referring to the reopening of the Baltic sea for navigation, after the passing of winter, in order to receive help $-n$. n.) (s. n.) (Sveriges Riksarkivet, Kabinettet för Utrikes Brevväxlingen Utrikesdepartementet Föregångare, Huvudarkivet 1681-1952, E2D, 416, London, 1830).

78 Ibidem, 28.

${ }^{79}$ Ibidem, p. 28-29.

80 Ibidem, p. 30.

81 Ibidem, p. 31; December 17th 1830, Magnus Fredrik Ferdinand Björnstiera informed Count Gustaf Wetterstedt that, according to some news, inserted in "Journal de Commerce", on December $15^{\text {th }}$, the French Ambassadors accredited to Vienna, Berlin and London were authorized to declare "que si la Prusse ou l'Autriche se joignent aux Russes pour réduire la Pologne, la France considera une telle intervention, comme déclaration de guerre contre Elle" (s. n.); a news that, in our opinion, has to be interpretated, as an expression of the French public opinion and of the republican opposition from the French Parliament and not as a real intent of the government; in this regard, the information, inserted in the same report catches our attention, according to this „le Général La Fayet (Maurice Joseph Paul Yves Roch Gilbert de Motier, Marquis de La Fayet, known under the name Lafayette, commander of the Nationa Guard, appointed in this dignity by King Louis Philippe, the leader of the republican opposition from the French Parliament-n. n.) a déjà porté le Toast de l'indépendance Polonaise, à un repas de Gardes Nationales" (s. n.) (Sveriges Riksarkivet, Kabinettet för Utrikes Brevväxlingen 
As far as it concerned it, Russia constantly refused the French mediation offers, even banning the insertion of a speech of the French King on this subject, in the Russian press. Or, the reason invoked by Vice Chancellor Karl (Carol) Robert Vasilievici Nesselrode, to justify this measure was "que Nous ne voulons point autoriser l'opinion que nous avons admis les bons offices, dont il est fait mention dans son discours" (s. n.) ${ }^{82}$. After he declined all the French attempts to offer mediation in favor of the Poles ${ }^{83}$, on January $3^{\text {rd }}$ 1832, Nicolas I incriminated "this deplorable system which the Propaganda has made France adopt, and which has been imitated in other countries, has already produced the most disastrous results in the Kingdom of Poland" (s. n.) $)^{84}$.

So, the French government, starting from 1830, made only diplomatic undertakings in favor of the Polish insurgents, but "ne les avait point encouragés dans leur noble mais périlleuse entreprise" (s. n.) ${ }^{85}$. The same policy line was adopted by the governments that followed, especially that led by the banker Casimir Pierre Périer, which came to power on March 13 $3^{\text {th }} 1831$, and whose program of government was defined as being "on the middle line: in domestic policy, order without sacrificing liberty, in foreign policy, peace without damaging the honor" of France (s. n.) ${ }^{86}$. And the one who strictly applied this policy in the Polish Question, was Horace François Sebastiani de la Porta. Even from the beginning of the Polish insurrection, in November 1830, Sebastiani refused to respond to the requests of support came from the Polish insurgents, arguing that he did not want to provoke the Tsar's "wrath".

\footnotetext{
Utrikesdepartementet Föregångare, Huvudarkivet 1681-1952, E2D, 416, London, 1830), also another, comeing from the same diplomat, which, on January 11th 1831 , informed Count Gustaf Wetterstedt that „le Général Lamarque (Jean Maximilen Lamarque, a supporter of the insurrections from Poland and Italy $-\mathrm{n}, \mathrm{n}$.) avait annoncé pour aujourd'hui une motion dans la Chambre des Deputés en faveur des Polognés, qui sera vivement soutenue par l'extrème gauche" (Sveriges Riksarkivet, Kabinettet för Utrikes Brevväxlingen Utrikesdepartementet Föregångare, Huvudarkivet 1681-1952, E2D, 417, London, 1831).

82 The report of Nils Fredrik Palmstierna to Baron David Schulzenheim, August $13^{\text {th }} / 1^{\text {st }} 1831$, in Sveriges Riksarkivet, Kabinettet för Utrikes Brevväxlingen Utrikesdepartementet Föregångare, Huvudarkivet 1681-1952, E2D, 701, Petersburg, 1831, iuli-dec.

83 In November 1831, for example, in the Dispatch sent to Carl Osipovici Pozzo di Borgo, the Russian Ambassador to Paris, it was mentioned that „le Cabinet Impérial ne pourrait plus recevoir de la part du Cabinet Français aucun ouverture relativement au Royaume de Pologne ou aux rebelles Polonais" (s. n.) (Riksarkivet, Kabinettet för Utrikes Brevväxlingen Utrikesdepartementet Föregångare, Huvudarkivet 1681-1952, E2D, 703, Petersburg, 1832)

84 Mape of Europe, Vol. II, p. 889.

85 M. O. D'Haussonville, op. cit., p. 31.

86 Istoria Franței. Coordonatori Jean Carpentier, François Lebrun. Preface by Jacques Golf, Traducere Aurelia Stoica, Institutul European, Iaşi, 2001, p. 281.

108
} 
However, he promised to the Poles he would try to mediate between them and Russia. An attempt that had a total fail in January 1831, as it was to expect. Then, when the Russian armies occupied Warsaw, on September $8^{\text {th }}$ 1831, he communicated to the Chamber of Deputies "la chute de l'héroique Pologne, par ces mémorables paroles: l'ordre règne à Varsovie" (s. n.) ${ }^{87}$. Touched by this "goodwill” sign, from the high French dignitary, Tsar Nicolas I hastened to restore diplomatic relations with France, the Duke of Trévise taking the post of Ambassador of France to St. Petersburg. Thus, the predictions of William A'Court, Baron Keytesbury, Ambassador of Great Britain to St. Petersburg, according to which, even if it wanted to respect the peaceful assurances give to Russia, France „may not have the power, to resist the fresh impulse that will be given by such circumstances to the faction, whose interest live in disorder and confusion", were refuted (s. n.) $)^{88}$.

The international reaction to the suppression of the Polish insurrection by Russia, in November 1830, were under the auspices of the confusion of the Polish cause with the "insurrectional" principle, which "leur avait mis les armes à la mains" (s. n.) ${ }^{89}$. This was, actually, the interpretation given to the events by Austria90, but also by Sweden.

The United Kingdom of Sweden and Norway, with direct interests in the Baltic sea area and with more specific ones in the Eastern question, adopted a position, in some ways, singular, towards the Polish Question. Sweden's internal and external political circumstances in which, in 1810, the famous marshal of Napoleon I, Jean Baptiste Sebastien Bernadotte, was

\footnotetext{
87 Biographie des célébtités militaires des amées de terre et de mer de 1789 à 1850. Par M. C. Mullié, Tome seconde, Paris, f. a., p. 530.

88 Veniamin Ciobanu, op. cit.

${ }^{89}$ M. O. D'Haussonville, op. cit., p. 29.

90 According to an account of the French Ambassador in Vienna, Nicolas Joseph Maison, Metternich would have said to him: „Croit-on que, comme homme, je puisse être insensible à la vue de tant de courage? Et pense-t-on que, comme ministre, je n'aimerais mieux avoir pour voisin une Pologne toujours bienveillante et toujours amie, qu'une Russie toujours envieuse et toujours envahissante? (s. n.) (ibidem); in this regard, there is also an information sent to Stockholm by Nils Fredrik Palmstierna, on August $13^{\text {th }} / 1^{\text {st }} 1831$, according to which he found out, from the first moment when the Court of Austria found out about the French demarches aiming to determine the Tsar to accept their mediation in the war with the Polish insurgents, "a fait dit ici (at St. Petersburg - n. n.) qu'elle espérait bien de voir rejeter cette offre de médiation, l'exemple de la Belgique (he was referring to the revolution from Belgia, started on August 25 th $1830-n$. n.) ayant abondamment démontré où l'on arrive par les interventions du genre" (s. n.) (Riksarkivet, Kabinettet för Utrikes Brevväxlingen Utrikesdepartementet Föregångare, Huvudarkivet 1681-1952, E2D, 701, Petersburg, 1831, iuli-dec.)
} 
proclaimed crown prince, prince of Pontecorvo, under the name Karl Johan, King Karl XIV Johan, from 1818, as the creation of the Swedish-Norwegian personal Union, determined the Swedish-Norwegian diplomacy coddle the Russian interests in the Polish Question as well as in the Eastern Question. In the Polish Question, the one under our analysis, this was also because the insurrection of November 1830 started in the international conditions mentioned above and due to the fact that the liberal internal opposition to the conservative and absolutist monarchical policy of King Karl XIV Johan was becoming more active.

For, although he had its social origins in the middle class of the French society, and owed his entire career to the French Revolution of 1789, he accepted with great difficulty restrictions imposed to the monarchic power by the Constitution of 1809, which replaced the absolute monarchy with a constitutional one, according to which the King could not exert his power "qu'avec la caution de conseillers responsables"91. During his entire reign (1818-1844), his political conceptions were highly conservative, for the application of which he used the services of a protégée, the aristocrat Magnus Brahe, who become his almighty personal counselor ${ }^{22}$. As a consequence, in the '30s, all the Parliament's (Riksdag) sessions were performed under the sign of violent confrontations with the King's government and his private collaborators. And, between its sessions, the King "combattait une presse libérale sans cesse plus nombreause et bruyant en interdisant des journaux et en faisant des procès à leurs éditeurs responsables" (s. n. $)^{93}$. In those circumstances, more dangerous than the possibility that the Polish insurrection would sharpen the liberal opposition was the fact that could have constituted a reason for the Norwegians to evade the personal Union, which they did not favor and against which they fought, first through arms then through institutional ways.

This is why the Swedish diplomacy paid close attention to the events in the Kingdom of Poland and in Lithuania, even from their beginning ${ }^{94}$, its

\footnotetext{
91 Jörgen Weibul, La Suède. Un aperçu historique, Institut suédois, 1993, f.l., p. 92.

92 Thus, him must have been addressed by "non seulement le Conseil, mais aussi le prince Oscar, fils unique de Charles-Jean, lorsqu'ils voulaient avoir l'oreille du roi" (s. n.) (ibidem).

93 Ibidem, p. 93.

$94 \mathrm{See}$, in this regard, Veniamin Ciobanu, Informatii din surse diplomatice suedeze privind ecoul în Rusia al declanşării insurecției poloneze din noiembrie 1830, in „Romanoslavica” New series, vol. XLVI, nr 3, University of Bucharest Publishing House , 2010, p. 5-18; idem, Data pertaining to the outbreak of the Lithuanian insurection (25 March 1831, retrived fron Swedish diplomatic sources, 110
} 
representatives, in St. Petersburg or London, manifested sometimes, on personal basis, and only for the use of Stockholm decision makers, a certain degree of sympathy and understanding towards the insurgents, without hesitating, at the same time, to reveal their weak points ${ }^{95}$. Officially, the Swedish government adopted a position appropriate to its line of policy, mentioned above. Thus, the Foreign Minister, Count Gustaf Wetterstedt, mandated Nils Fredrik Palmstierna to ensure the Russian Vice Chancellor and Foreign Minister, Karl (Carol) Robert Vasilievici Nesselrode "de l'impression pénible que le Roi (Karl XIV Johan - n. n.) a eprouvé en apprenant une nouvelle aussi chagriant pour l'Empereur (Nicolas I - n. n.), que l'était celle de la révolte en Pologne", mission which he accomplished without any delay (s. $\mathrm{n} .{ }^{96}$. At the same time, the Swedish government assured its Russia counterpart that the King did not intend to grant audience to an emissary of the Polish insurgents who would have asked for support from Sweden ${ }^{97}$, and that the King will always keep the same attitude of loyalty to the Tsar and, of course to its interests in Poland ${ }^{98}$. Besides, as Nils Fredrik Palmstierna noticed, in the ruling circles of the Russian Empire there was no doubt about the feelings of the Swedish King towards the Tsar "ni sur la constant loyauté d'une politique, dont cette qualité forme la base" (s. n.)99.

The order of the Foreign Minister to refuse the request of Marquis Wielopolski of a Swedish passport for a Polish emissary, sent to Magnus Fredrik Ferdinand Björnstiera, was following the line of the same policy. The

in „Revista Română de Studii Baltice şi Nordice (The Romanian Journal for Baltic and Nordic Studies) ; Vol. 3, Issue 1 (2011), Târgovişte, p. 65-86.

95 "C'est un coup desespéré - thought Magnus Fredrik Ferdinand Björnstiera, in a report adessed to Count Gustaf Wetterstedt, on December 14th 1830 , - que celui qu'ont joué les Polonais. Sans frontières, sans forteresse, sans argentt, cernés dde tous côtés, par les copartageans (meaning Austria, Prussia and Russia, the three European Powers that made those divisions of Poland, in 1772, 1793 and 1795 - n. n.), sans ports de Mère, et sans communication quelconque avec des Puissances interessées à leur restauration ce ne serait, que par les efforts les plus heroiques, et par l'union la plus parfaite, que pourrait se retablir cet ancien boulevard de l'Europe"; totuşi, nu omitea el să adauge că "je crois les Polonais capables de la première de ces conditions, mais non de l'autre"; because, "l'histoire en fait preuve. C'est leur désiunion, que toujour les a perdîu" (s. n.) (Sveriges Riksarkivet, Kabinettet för Utrikes Brevväxlingen Utrikesdepartementet Föregångare, Huvudarkivet 1681-1952, E2D, 416, London, 1830).

96 See his report from January $8^{\text {th }} 1831$ /December $27^{\text {th }} 1830$, in Riksarkivet, Kabinettet för Utrikes Brevväxlingen Utrikesdepartementet Föregångare, Huvudarkivet 1681-1952, E2D, 701, Petersburg, 1831, Jan-iuni.

${ }^{97}$ His report from February $15^{\text {th }} / 3^{\text {rd }} 1831$, in ibidem.

${ }^{98}$ His report from August $13^{\text {th }} / 1^{\text {st }} 1831$, in ibidem, Iuli-dec.

${ }^{99}$ His report to Count Gustaf Wetterstedt, from January $29^{\text {th }} / 17^{\text {th }} 1831$, in ibidem. 
Swedish diplomat not only hastened to comply with the order but also advised Wielopolski to give up any undertaking in this way, because he knew the position on the Swedish court towards the Polish insurrection ${ }^{100}$.

Noteworthy is the fact that the opinions of the Swedish diplomats, who approached problems concerning the Polish insurrection in their reports, oscillated between its justification and, from certain point of views, its reprobation, also expressing some reserves and critics towards the measures adopted by the Tsar for its suppression but also approving some. Very conclusive, from this point of view, are the opinions of Nils Fredrik Palmstierna, an informed observer and analyst of those events. In his opinion, "dans l'affaire de Pologne, comme dans la plupart des affaires semblable, l'histoire devra écouter les deux parties pour asseoir un jour le jugement, qu'elle prononce sans appel. Elle repoussera les déclamations banales des anarchistes, comme vaines et ne prouvant rien; mais elle s'occupera à récueillir les faits vérifiés. Elle prononcera, selon toute apparence, que si rien ne saurait justifier ni la rébellion même, ni les actes atroces, qui en signalèrent les premiers momens, il y a néanmoins des faits, qui suffisent pour expliquer la première. Si l'une des deux parties est condamnée, comme elle ne manquera de l'être, l'autre ne sera pas absonte; l'Empereur, personnellement, sera peut-être le seul qui, aux yeux de l'impartialité, Se trouvera excusé" (s. n.) ${ }^{101}$. He thought that the insurrection could have been avoided, or, at least, would have had a less fateful evolution, if the Polish nobility would have known its real interests. This did not happen because the biggest part of it was deceived ,aux illusion du moment, nouris par les phrases intolérables des philosophes folliculaires du pavé de Paris, dont la présomptieuse igneurance et dont souvant l'insigne mauvaise foi prêche avec impudeur les sotisses les plus absurdes, comme s'il c'étaient des axiomes" (s. n.) ${ }^{102}$.

More extensive are his consideration formulated on a different occasion. Commenting the measures adopted by Tsar Nicolas I, after the defeat of the insurrection, in November 1830, he analyzed them from a double perspective: on one hand, as coercive measure and on the other as

\footnotetext{
100 His report from March 24th 1831 , to Count Gustaf Wetterstedt, in Sveriges Riksarkivet, Kabinettet för Utrikes Brevväxlingen Utrikesdepartementet Föregångare, Huvudarkivet 1681-1952, E2D, 417, London, 1831; on this occasion, he solicitated instructions in order to know how to act, in the future, in similar cases (ibidem).

101 See his report to Gustaf Wetterstedt, from February 9th/January 28th 1831, in Sveriges Riksarkivet, Kabinettet för Utrikes Brevväxlingen Utrikesdepartementet Föregångare, Huvudarkivet 1681-1952, E2D, 702, Petersburg, 1831, Jan.-Juni.

102 Ibidem.
}

112 
concessions made to the Poles; concerning those from the first category, he also presented them in a double perspective: apparently rigorous, if they were put in connection with the fact that the offenses of the Poles were committed "dans le sens de liberalism", especially that the rebellion had its antecedents in "le souvenir de grandes injures politiques dont cette nation a été victime depuis 1772"; on another hand, he granted Tsar Nicolas I mitigating circumstances; regarding the new political organization of the Kingdom of Poland that was expected, he considered that it "ne lui laisse que l'ombre d'une existence politique à parte", and, among the motivation of that state of things, he underlined, especially, the importance of a direct and unlimited control of Russia over the Kingdom of Poland, from the perspective of the achievement of its objectives in continental policy and in the Eastern Question, as long as, without that control „elle devrait renoncer en même tems à la prépondérence Européenne qu'elle n'exerce à ce degréque depuis qu'elle possède la Pologne; même à Constantinople elle ne dicterait plus la loi"; he also accused a series of other measures adopted by the Tsar, which had no justification and which "parraissent se faire comme exprès pour humilier et pour aigrir, sans qu'il en résult une nouvelle force pour le Gouvernement" (Russian - n. n.), ni une garantie additionelle contre les révoltés"; and among the possible causes that determined the adoption of those measures, he indicated the fact that "l'on veut faire vivement sentir, jusque dans les choses minimes, que désormais il n'est pas question de nationalité et faire disparaitre tout ce qui peut la rappeller. Peut-être croirat-on que de cette manière la résignation, pour être plus complète, n'en sera que plus facile et qu'insensiblememnt les idées se modifieront par l'habitude"; also, he thought that the effects of the insurrection could have been perceived differently by the provinces; at the same time, Nils Fredrik Palmstierna signaled the persistence of a strong state of tension which could have triggered, at any moment, new and serious disturbances, including in territories annexed by Austria and Prussia, his conviction was that Poland „sera toujours un élément dissolutif du systême Européenne, jusqu'à l'époque où l'une et l'autre seront reconstruits sur des nouvelles bases"103.

Therefore, the Polish insurrection of November 1830 started during a very tensed international situation and was one of the most remarkable political and military events of the beginning of the fourth decade of the

103 See his report from May 26 $6^{\text {th }} / 14^{\text {th }} 1832$, in Sveriges Riksarkivet, Kabinettet för Utrikes Brevväxlingen Utrikesdepartementet Föregångare, Huvudarkivet 1681-1952, E2D, 703, Petersbug, 1832. 
nineteenth century. Due to the circumstances in which it started and because of the possibility of provoking a new configuration of the political map of Europe, the event caught the attention of the Great Powers of Europe. However, their attitudes towards the insurrection were determined by reasons deriving from their particular interests, which, at that time were towards maintaining the peace in Europe. Thus, Tsar Nicolas I could suppress the Polish insurrection with his own forces, on one hand, because he managed to impose the idea that the turmoil in the Kingdom of Poland was an internal question of the Russian Empire, and on another "because at that moment the Polish cause did not became a international question" (s. n.) ${ }^{104}$.

Translated by Cosmin Mihuț.

104 Leonid Boicu, op. cit., p. 490. 